\title{
A Profit Game - The Law and Economics Analysis on China's Gene Privacy Problem
}

\author{
Wenya Zhou \\ Department of Law and Economics \\ Sichuan University \\ Chengdu, China
}

\author{
Suiquan Yang \\ Department of Law \\ Sichuan University \\ Chengdu, China
}

\begin{abstract}
With the development of gene technology, the issue of gene privacy and information utilization has been hotly discussed. The protection of gene privacy makes more people accept genetic diagnostic tests, but excessive privacy protection oppositely increases the cost of gene research and threatens to gene technological progress. It looks like that the issue is about the moral and legal constraints, but virtually the profit game between protection of the genetic privacy and genetic information using is hidden behind. Gene providers want to reduce the cost of protect privacy, developers need to access to genetic resources to generate greater profits. Due to the information asymmetry between them, the balance cannot be formed. Both sides tend to pursue their own interest maximization. Law is for the protection of the weak, and economics is for efficiency. Legislation needs to balance the interests of both sides and the public to determine the specific rules of operation. According to microeconomics, under the condition of constant demand, insufficient supply will lead to price increase, which can increase the income of the relevant parties to obtain privacy, thus increasing the possibility of infringement. In China, due to the game of multiple profits, it is difficult to balance the rights and interests of all parties involved in the legislation of gene rights. This paper makes a law and economic analysis of gene privacy and clarifies the important principles of gene privacy in order to improve the legal system for protecting gene privacy and using genetic information. The author believes that only by allowing the parties to negotiate on collection, utilization and custody, can the overall welfare of the society be improved. The government should participate in the establishment of a gene bank regulatory system to ensure the safety of genetic information at the source and eliminate public concerns about the safety of gene privacy. Gene privacy supervision should consider the differences between countries, and clarify the rights and obligations of the multi-level regulatory system from aspects of legal supervision, government supervision and industry supervision, which was effective to prevent illegal use of genetic information.
\end{abstract}

\section{Keywords—gene privacy; law; economics analysis}

\section{INTRODUCTION}

In 2015, the United States proposed the implementation of the precision medical program. In 2016, the Chinese Academy of Sciences announced the launch of the Chinese population precision medical research program. In the near future, human beings will be brought into the precise medical system from birth and provide genomic data for precision medical services. Technically, accurate medical care is undoubtedly a very high quality medical service, which can greatly reduce the improper use of clinical drugs, improve the curative effect and reduce medical costs, and can effectively improve the health and life of the people. But most people refuse to use genetic testing in treatment or clinical trials, because they fear that insurance companies or others may use these results to have a negative impact on themselves (Kilbride 2018). [1]Although the greater value of gene disclosure in identifying potential genetic diseases or looking for relatives, people do not make wise decisions about their most important information. People are not fully aware of the potential risks of reidentification, law enforcement agencies' access to data and genetic contamination (Rodriguez 2018). [2]

As a product of modern medical science, gene technology brings convenience to people, and it also induces new social problems. It needs to be solved by means of law. With the further development of precision medical technology, the issue of gene privacy has been heated. In 2008, the United States signed the GINA(Genetic Information Nondiscrimination Act), which prohibits insurance companies from insuring them or raising insurance costs on the grounds of genetic disease genes, and prohibits employers from any decision on employment, dismissal, appreciation, and salary increase on the basis of genetic information (Rothstein 2018).[3] Influenced by it, various countries in the world have started legislation on gene privacy protection. Health care and insurance companies believe such a ban will increase their cost. Due to the game of multi-interests, it is difficult to balance the rights and interests of all parties involved in the legislation of genetic rights, and the relevant legislation in China is still stagnant. This article is to analyze the genetic privacy by law and economics, to clarify the important principles of gene privacy and to improve the legal system of the protection of gene privacy and the anti-discrimination law in China.

At present, many problems are accompanied by the development of gene technology (Henderson 2014). [4]First of all, on the issue of genetic equality, once the genetic information is disclosed, it is likely to cause insurance companies, employers and educational institutions to discriminate against "gene defects". For example, the "first 
case of genetic discrimination" [5]caused by the examination of civil servants in Foshan, and the first case of the prenatal genetic diagnosis of hemophilia in China are all due to the lag of the law that causes the victims to be difficult to defend their rights. In the United States, leaks of classified medical information are also on the rise, and these data may be mistakenly used to inform criminal enterprise agencies.[6]In recent years, both domestic and foreign infringement of personal genetic privacy has happened, so it is very important to make the personal right of gene privacy more clearly in the category of legal protection in China.

Secondly, on the question of gene information, who is the owner of individual gene information, individual, family collective or state ownership? Liao (2009) believes that the main reason for sharing genetic information among family members is that genetic information is essentially familial. [7]Weaver (2015) studies suggest that genetic tests reveal the health of the patient and predict the future health of the patient, while also potentially disclosing health information related to other family members. [8]With the availability and affordability of gene detection and the combination of genetics and mainstream medicine, it is important to clarify the importance of confidentiality and the rules of genetic disclosure about genetic relationships. In order to avoid the leakage of genetic information, who should keep the gene information, there are also the circumstances in which the gene information can be transmitted, the imputation of the genetic information and the compensation for damage are revealed. The potential commercial value attribution of genetic information.

Finally, in the dispute between gene providers and medical and other institutions involved in genetic information, doctors or researchers use individual genes to study patent results for profit without the permission of the gene provider. Or deliberately divulging the patient's genetic information to others for profit, or finding someone stealing the patient's test results without stopping. These acts, on the surface, do not directly infringe on the human body or any rights on the property, but in essence, indirectly cause property and mental damage to the gene provider. In the case of gene detection, the doctor did not tell the patient that he did not have the test qualification. It was essentially a violation of the right of gene privacy, and I think it should be responsible for it.

\section{THE THEORY AND LEGISLATION OF GENETIC RIGHTS}

\section{A. The Theory and Law of China}

In China, the regulations on the management of human genetic resources are only the provisions of the management of human genetic resources. On October 31, 2012, the Chinese government promulgated the Regulations on the Management of Human Genetic Resources (Draft for Consultation) and solicited public opinions. The draft stipulates that any organization and individual may not engage in the research and development of human genetic resources that may result in the consequences of discrimination, and shall not buy or sell or trade the material of human genetic resources. It is said that human genetic resources refer to the resources and materials, such as organs, tissues, cells, nucleic acids and nucleic acid products containing the human genome, genes and their products, and the information they produce.

At present, there is still controversy about whether genetic rights belong to civil rights or citizens' basic rights. Li Yan (2008) wrote an article on people's civil rights to their genes.[9] Li Wen and Wang Kun (2002) also believe that genetic privacy discrimination can be included in the traditional right of privacy, and there is no need to establish a new legal system to solve the problem of genetic privacy. [10]Lin Yanling (2005) believes that with the increasing progress of gene technology, personal gene privacy is constantly being violated. [11]Contemporary civil law should use the right form of genetic privacy to protect gene privacy.

We believe that the protection of genetic rights in China is still in a very vague state. It should be protected by a complete genetic privacy law for the problem of the invasion of the right of genetic privacy. There is a difference between the potential value of genetic privacy and ordinary privacy. The government should intervene in the management and protection of genetic privacy to avoid causing extreme events to endanger families and survive.

\section{B. Theory and Legislation of Other Countries}

Scholars from other countries discussed the policy to protect gene confidentiality (Resnik 2009). ${ }^{[12]}$ Ensuring that individuals sharing genetic information with medical researchers are protected normally by subjects (Wasson 2009).[13]Malm (2009) believes that individuals should consider sharing their genetic information as the risk of harm diminishes and the benefits to others increase. [14]Kilbride believes that patients should be given a warning obligation to open genetic information to others, and people should prevent, reduce or reduce the risk of harm to others when the expected harm is serious and the cost or risk is moderate enough. Henderson studied how to obtain consent and handle the potential reward of individual genomic outcomes as genome sequencing entered clinical practice. [15]Rao (2017) compares three frameworks for regulating the human body. The conclusion is that contracts and privacy rights cannot compete with property paradigm. [16]Berkman (2017) discussed the right to know about genes and supported the return of high-value genetic information without asking for unknown preferences. [17]

At present, the protection of genetic privacy legislation in various countries can be divided into three types: direct protection, indirect protection and generalized protection. The United States, Germany and France adopted direct protection. Their law stipulates in detail the content, nature, liability constitution, tort and compensation scope of the right of gene privacy. When the right of genetic privacy is infringed, the victim can take it as an independent complaint and ask the court for legal remedies, because the law acknowledges that the right of privacy is an independent personality right. The sixteenth article of the French civil code produced more than 100 legal rules about the "right to 
life" and "the right to personality" in the course of its implementation, and has enacted several dozens of relevant special law "deathbed natural death law" and dozens of detailed rules and regulations. With the genetic and genetic discovery of human beings and related technological innovations, the civil code added $16-10$ to $16-13$ and 5 rules of implementation, written into special chapters on human genetic research and identification, and produced specific regulations on the use and identification and research of human genes.

The first volume (civil rights) of the French Civil Code (civil rights) is increased by third chapters (the examination of human genetic characteristics and the identification of people through genetic characteristics), which specializes in "genetic rights". According to the second chapter on "respect for the body", the genetic rights in the civil code includes human dignity, the human body and its components and the non-property, the integrity of the human body and gene, the scientific and medical purposes of the genetic examination, the informed consent, the genetic identification, and the prohibition of genetic discrimination. And so on.

British law is an indirect way of protection. The victim can only attach this kind of genetic damage litigation to other cases, and classify the cases of the right of gene privacy into other cases of tort, and there is no independent litigation of genetic privacy. Japan is a general protection. It does not make specific provisions on the object, content, and responsibility of the right to genetic privacy, but only in civil law, relevant laws or cases, and does not list specific provisions, nor does it enumerate specific contents, so it is not conducive to practical operation.

We believes that China should establish a complete and independent protection system for genetic rights, in order to replace the inequality of society with substantive equality, give priority to the rights of carriers of defective and variant genes, so as to achieve social justice.

Economists believe that the root of "discrimination" lies in the scarcity of resources, to change the discrimination is to change the unequal distribution of resources. On the other hand, to study technology, we must clarify ethics. The legal question about human science experiment is not only the problem of public law management, but also the innovation and establishment of many difficult legal rules in the field of private law. Lack of genetic knowledge, weak awareness of rights and absence of national protective measures are the main reasons for the damage to the interests of ordinary gene providers. The objective factors that hinder genetic rights should be promoted to legal facts, the moral obligations should be transformed into legal obligations, and the illegal obligations should be infringed. In content, the protection of genetic rights should include gene detection, gene consultation, gene therapy, gene patent protection, prohibition of misuse of gene data, and protection of gene resources.

\section{LAW AND ECONOMICS ANALYSIS ON GENE PRIVACY}

\section{A. Analysis of Interests Game}

The right of genetic privacy contains both personality interests and economic interests. Economic analysis can be used to analyze the economic interests in the right of genetic privacy. In any particular case, any actual moral obligation exists, at least in part, depending on the balance between risk and interest. [7]"Table I" showed the random choice between gene providers and research institutes, and the numbers in the table represent the changes of interests of both sides before and after the game respectively. If the patient does not provide genetic information, it is unable to obtain effective medical treatment, so the income of the patient is 0 , and the medical institutions cannot obtain the benefit of the research through the genetic information, so the medical institution also gains 0 .Assuming that the patient provides genetic information to get more effective and efficient treatment, the gene provider gains 1 and the medical institution does not disclose privacy, with a return of 0.5 . On the contrary, if a medical institution leaks genetic information, especially some disadvantageous information, it causes mental and economic damage to the gene provider, such as loss of job opportunities or loss of insurance opportunities, and the loss to the gene provider is expressed in -1 , and the relative medical institutions are obtained by disclosing genetic privacy information. However, in the case of involuntary provision by the gene provider, medical institutions may take improper infringement behavior to obtain their genetic privacy information, and take a part of the cost of tort and reduce the income to 0.5 .

According to the above analysis, the best strategy for gene providers is to provide their own genetic information, while medical institutions do not disclose their genetic privacy. But for medical institutions, it may be impossible to gain more benefits without leaking, and may choose to divulge privacy, regardless of whether gene providers voluntarily provide genetic samples, and divulging genetic information is a dominant strategy. Only by increasing the cost of infringement of genetic privacy information in medical institutions can we prevent the occurrence of infringement.

\section{TABLE I. RANDOM CHOICE BETWEEN GENE PROVIDERS AND} RESEARCH INSTITUTES

\begin{tabular}{|c|c|c|}
\hline & Reveal & Not Reveal \\
\hline voluntary provision & $-1,1$ & $1,0.5$ \\
\hline Involuntary provision & $-1,0.5$ & $0,0.5$ \\
\hline
\end{tabular}

\section{B. Analysis of Cost and Benefit}

Next, we will analyze the cost of genetic privacy. For Gene Providers, there is a cost of protecting privacy, and the use of genetic privacy is divided into the benefits of providing genetic privacy, or the benefit of hiding the privacy. When the benefits of providing privacy are greater than the sum of the benefits of protection and privacy, gene providers provide their own privacy, such as providing their own genetic data to medical institutions for better treatment 
when some genetic diseases are treated. At this point, providing their own genes is greater than hidden benefits, and patients are willing to provide genes.

For gene users, the cost of obtaining gene privacy includes the cost of purchasing information, the cost of information analysis, and the cost of studying genes. If information is obtained through infringement, the cost also includes the cost of infringement, the social consequences and the social sanctions imposed by the illegal act. In the case of equal income, when the cost of obtaining genetic information is less than the cost of obtaining the infringement, the gene holder or the negotiation is obtained by negotiation. If the cost of obtaining the privacy of the gene is smaller, the user will get through the infringement. When the use of human genes is greater than the cost of infringement, tort may occur. If the amount of the tort compensation is too low, it cannot act as a deterrent, the remedy of the right of gene privacy is mainly by the compensation for mental damage. The current tort compensation in our country is to compensate for the loss, and there is no punitive compensation system.

\section{Analysis of Total Social Welfare}

Kaldor - Hicks efficiency believes that if one party gains a profit and the other is damaged in a transaction, the gains of the beneficiaries are sufficient to make up for the loss of the damaged person (regardless of the fact that this is actually happening), indicating that the overall social welfare is increased. The leakage and abuse of genetic data produce negative external effects, resulting in more consumption of judicial resources. In order to reduce the cost of gene protection, it is necessary to restrict the infringer's behavior in law, so as to internalize the cost of gene privacy protection. From the perspective of institutional economics, it is necessary to increase the infringement cost of infringers.

Legal reform inevitably involves changes in interests and how to improve the total surplus of society. Genetic privacy protects human rights, but may increase the cost of health care. The standard of "potential Pareto improvement" is that as long as the profit of the beneficiary is greater than the loss of the damaged person and the loss of the injured person can be compensated by the beneficiary, it will increase the social income. Genetic privacy disputes are mainly caused by information asymmetry of low efficiency, how to eliminate the impact of information asymmetry, improve the efficiency of economic activities. The two sides do not have a fully effective incentive mechanism. In order to internalize costs, the infringer must fully compensate the victims. The law should improve the system by minimizing transaction costs and correcting market failures.

\section{The Suggestions of ChInA’s Gene PrivaCy LEGISLATION}

In conclusion, the law is to protect the weak, and economics is to improve efficiency. China's legislation needs to balance the interests of both sides and society to determine the specific rules of operation.

\section{A. Improving the Legislation of Genetic Rights}

It is suggested that the legal protection system of genetic rights should be established at the legislative level, and the legal protection system and relief measures against genetic rights should be perfected. We thought that China should comply with the development of the times and make legislation on the rights of gene related as soon as possible. In the aspects of privacy protection, it is a tort that the paradigm of illegal spying, disclosure, disclosure of other people's genetic information and the implementation of genetic discrimination in employment, insurance and promotion should be of the corresponding legal responsibility. In China, the current tort compensation only requires the tortfeasor to bear the liability of tort for its damage, thus making the victim as possible as possible to restore to the state before it is not infringed. We believed that the infringement of genetic privacy involves indirect infringement and more mental loss, and punitive damages regulations can be set up properly, and special laws are required to regulate this kind of harm.

The generation of genetic rights stems from the continuous development of gene medical technology.

Only the gene activities carried out by laws and regulations are protected by law. The gene technology law in France or Germany can be used for reference in China's legislation. At present, Germany conducts about 100,000 genetic tests a year, many of which are carried out by employers to ensure that employees or job seekers do not have serious health risks. In the future, this examination may also be a common measure in the health inspection of the workplace in China, which may cause the workers' health privacy exposure to be discriminated by employers' genes. In reality, there is not only discrimination against the carriers of genetic defects, but also the possibility that the rich can spend money to optimize their own genes, so as to discriminate against the poor, and thus deprive the equal rights of life, the right to development, and completely deny the principle of equality for all.

\section{B. Setting up a Regulatory System for Gene Bank}

The government should take part in establishing a gene bank supervision system to ensure the safety of genetic information at the source. The regulation of gene privacy should take into account the differences between countries and clear the rights and obligations of the multilevel regulatory system from three aspects of legal supervision, government supervision and industry supervision, and effectively prevent the illegal use of genetic information.

The management organization should strengthen the control consciousness of the organization sample. As a source of genetic information, tissue samples are strictly controlled. To ensure the safety of genetic information at the source, we can make the protection of genetic information privacy more comprehensive. Because of the information asymmetry between the regulators and the parties, it is difficult for the parties to know the information of gene regulation in normal circumstances, so it is not effective to evaluate the supervision. The regulatory authorities should 
take the initiative to communicate with the parties so that they can understand the safety situation. Information asymmetry between departments is also a major reason why genetic disputes are difficult to deal with. When accidents occur, how to deal with them should be done, and a set of perfect appeals should be set up.

\section{Formulating Rules for the Collection, Utilization and Preservation of Genetic Information}

At the same time, allowing the parties to negotiate, collect, use and keep in order to enhance the overall welfare of the society. In order to effectively stop the illegal use of genetic information, the law should allow the parties to negotiate the collection, use and storage of genetic information. But at the same time, the law should make a limitation to decide which agreement should be invalid. This not only safeguards the party's autonomy of will, but also ensures the rational flow of genetic information, to eliminate adverse social effects. The law should give patients the basic warning obligation for family genetic information about crisis life and safety. Genetic trust funds can be established to provide compensation for victims and limit defendants.

\section{Multifaceted Protection of Gene Privacy}

System innovation can be carried out and the third party test system should be established. To make up for the shortage of government resources, we should make use of the popularity of the Internet to establish a regulatory platform for the close relationship between the government and citizens. The use of genetic information can be adjusted through the government's release of information and the participation of the public in discussions. We should make full use of the power of market, ethics and technology to protect genetic information. As practitioners in the field of gene science and technology, they should not only pay attention to their own scientific and technological affairs, but also take into account the ethical law and social factors. The field of science and technology should provide technical support for the protection of genetic information privacy, such as the use of more secret systems to protect genetic information.

\section{CONCLUSION}

We hope to realize the legal protection of genes by establishing the legal protection system of genetic rights and improving relief measures. The law of genetic rights concerns the most vital interests of citizens, as well as law, medicine, philosophy, biology, anthropology and many other disciplines. The formulation of the genetic right law should closely combine the research of other subjects on related issues and coordinate the relationship between various disciplines so as to formulate laws that meet the needs of the reality.

\section{REFERENCES}

[1] Kilbride, MK. Genetic Privacy, Disease Prevention, and the Principle of Rescue. Hastings Center Report. 48, 3, 10-17, May 2018.
[2] Rodriguez M. Who owns your genes?. Fortune [serial online]. August 2018;178(2):14. Available from: Business Source Complete, Ipswich, MA. Accessed August 1, 2018.

[3] Rothstein, MA. GINA at Ten and the Future of Genetic Nondiscrimination Law. Hastings Center Report. 48, 3, 5-7, May 2018.

[4] Henderson, GE; et al. The Challenge of Informed Consent and Return of Results in Translational Genomics: Empirical Analysis and Recommendations. Journal of Law, Medicine \& Ethics. 42, 3, 344355, 2014.

[5] https://baike.baidu.com/item/ The first case of genetic discrimination /3581784? fr=aladdin

[6] Thinkstock. 79K Patients Affected by Emory Healthcare Data Breach Health IT Security. 02 Mar 2017. Available from: http://health it security.com/news/ 79k- patients-affected-by-emory-healthcare-databreach

[7] Liao S M. Is There a Duty to Share Genetic Information?[J]. Journal of Medical Ethics, 2009, 35(5):306-309.

[8] Weaver M. The Double Helix: Applying an Ethic of Care to the Duty to Warn Genetic Relatives of Genetic Information[J]. Bioethics, 2015 30(3):181-187.

[9] Li Yan. On the civil rights of human beings to their genes [J]. Dongyue cluster, 2008 (4): 171-174.

[10] Li Wen, Wang Kun. Civil and Legal Protection of Gene Privacy and Gene Privacy [J].Journal of Wuhan University of Technology (Social Science Edition), 2002, 15 (2): 179-183.

[11] Lin Yanling. Genetic privacy and its protection in civil law [J]. Gansu Social Sciences, 2005 (3): 64-67.

[12] Resnik, D. 2009. Direct-to-consumer genomics, social networking, and confidentiality. American Journal of Bioethics 9(6-7): 45-46.

[13] Wasson, K. 2009. Direct-to-consumer genomics and research ethics: Should a more robust informed consent process be included? American Journal of Bioethics 9(6-7):

[14] Malm, H. Genetic privacy: might there be a moral duty to share one's genetic information?. The American Journal Of Bioethics: AJOB. United States, 9, 6-7, 52-54, 2009.

[15] Caulfield, T; Murdoch, B. Genes, cells, and biobanks: Yes, there's still a consent problem. Plos Biology. United States, 15, 7, e2002654, July 25, 2017.

[16] Rao, R. Genes and Spleens: Property, Contract, or Privacy Rights in the Human Body?. Journal of Law, Medicine \& Ethics. 35, 3, 371382, Sept. 2007.

[17] Berkman, BE. Refuting the right not to know. Journal of Health Care Law \& Policy. 19, 1, 1-72, Jan. 2017. 